\title{
Nutrient Composition and Digestibility of Asian Swamp EeL (Monoptrusalbus) Meal in Broiler Nutrition
}

\author{
Rene Wangiwang Pinkihan
}

Ifugao State University, Nayon, Lamut, Ifugao

\begin{abstract}
This study was conducted to determine the nutritive value and digestibility of Asian swamp EeL meal in broiler nutrition. Specifically, it aimed to: a) determine the nutrient composition of Asian swamp eel meal as compared to Peruvian fish meal b) determine and evaluate the digestion coefficients and the total digestible nutrient of the different proximate components, $c$ ) determine and evaluate the digestibility of the apparent digestible energy, apparent metabolizable energy and zero Nitrogen balance-corrected AME Contents of Asian swamp eel meal on as-fed basis and, d)determine and evaluate the digestibility of calcium and phosphorus contents of Asian swamp eel meal on as-fed basis. Asian swamp eel meal contained 68. $79 \%$ crude protein; 3. 95\% crude fiber; 5 . 21\% crude fat; 16. 70\% ash, 307. $41 \mathrm{kcal} / 100 \mathrm{~g}$ gross energy; $5.11 \%$ calcium; 3. $19 \%$ phosphorous; $612.04 \mathrm{mg} / \mathrm{kg}$ lysine; and $24.80 \mathrm{mg} / \mathrm{kg}$ methionine. Except for ether extract with a low digestion coefficient of 57. 02\%, digestion coefficients for other nutrients in Asian swamp eel meal are high.
\end{abstract}

Keywords: ASEM, Broiler nutrition

\section{Introduction}

Availability of feed protein is one of the various problems in the feed and livestock industries since feed quality highly depends on protein and amino acid contents of the feed mix. Feed quality is sacrificed without a sufficient and reliable source of these raw feed materials. As a consequence, animal performance is adversely affected.

Fish meal now is the only available source of complete amino acid, essential trace elements and minerals in animal and aquatic feed formulations. It isbecause, other sources of imported animal protein were banded due to the findings that these are carriers of some diseases (Gillespie, J. R. 1992). As the only source of high quality animal protein, and several countries are utilizing it, supply of fish meal in the world market is scares as a result, some feed mill establishments shifted on the use of fish meal made from filleting waste and white fish containing lower protein and excessive level of ash.

In view of these issues, one of the significant trends in animal feeding and nutrition is the documentation of locally available alternative sources of feed protein in animal feed formulations. The proliferation and rapid multiplication of the Asian swamp eel (Monoptrusalbus) in almost all bodies of fresh water including irrigation systems and rice fields in the countryside presents a logical answer to this problem. The Asian swamp eel or rice paddy eel is classified under the following taxonomic classification: Kingdom: Animalia, Sub-kingdom: Bilateria, Infra-kingdom: Deuterostomia, Phylum: Chordata, Class: Actinopterygii; Order: Synbranchiformes; Family: Synbranchidae, and, Sub-family: Neopterygii (www.columbia.edu/itc/cerc/danoff-burg/. . . /Monopterus_albus.html). The Asian swamp eel is not a true eel as it doesn't belong to the Anguilliae family; instead, it is a member of the fish family, Symranchidae (Asian Swamp Eel Fact Sheet, 2006). Asian swamp eel is scientifically known as Monopterusalba (Zuiew, 1793), Fluta alba (Bloch and Schneider, 1801) or M. javanensis (Lacepède, 1800). Its common English names include rice eel, rice field eel, white rice field eel, and rice paddy eel. Vernacular names are kiwet(Ilk. ) and belut (Bahasa Indonesia). The Asian Swamp Eel has an elongated snake-like body, with a blunt, rounded nose. It doesn't appear to have any fins, and its slippery skin is darker green or brown on the top, growing lighter towards the eel's underbelly. It has rows of very small teeth that appear more like bristles (Villiform) and smallish dark eyes. It has one, V-shaped gill opening on its underside, just below the head. The Asian swamp eel can grow to a length of one meter, which is about three feet long, and weigh up to one pound (Hamilton, 2006).

The Asian swamp eel meal may be an effective and efficient substitute for imported and diminishing high quality fish meal as feed protein source in animal feed formulations. However, the nutritive value and the digestibility of the Asian swamp eel meal has not been experimentally considered an important topic in poultry nutrition research in recent years. Hence, this study would like to determine the nutritive value ovarian swamp as compare with Peruvian fish meal, which is the most commonly used commercial animal protein source in most feed formulations for poultry. It also aims to evaluate the digestibility in order to determine the digestion coefficient of the different nutrients contained in the Asian swamp eel meal.

\section{Objectives of the Study}

Generally, this study was conducted to determine and evaluate the nutrient composition and digestibility of Asian swamp eel meal in broiler nutrition. Specifically, it aimed to:

1) Determine the nutrient composition of Asian swamp eel meal as compared to Peruvian fish meal,

2) Determine and evaluate the digestion coefficients and the total digestible nutrient of the different proximate components, 


\section{International Journal of Science and Research (IJSR) \\ ISSN (Online): 2319-7064}

Index Copernicus Value (2013): 6. 14 | Impact Factor (2015): 6. 391

3) Determine and evaluate the digestibility of the apparent digestible energy, apparent metabolizable energy and zero Nitrogen balance-corrected AME Contents of Asian swamp eel meal on as-fed basis and,

4) Determine and evaluate the digestibility of calcium and phosphorus contents of Asian swamp eel meal on as-fed basis.

\section{Materials and Methods}

Experiment1 - Chemical Analysis of Asian Swamp Eel Meal (ASEM)

Collection and processing of Asian swamp eel. Asian swamp eels were caught and collected from rice paddies, irrigation canals and creeks with direct current electricity. These were cut-opened to eliminate blood and entrails, and washed in running water to ensure that remaining blood were removed. Fresh eel meat was ground in a meat grinder, sundried until sufficiently brittle, and then pulverized into meal form. There were situations when fresh eel meat was subjected to gradual oven-drying at $60-75^{\circ} \mathrm{C}$ until 13-14\% moisture content was reached and brittle enough for grinding. These were situations when weather conditions did not allow sun drying. The swamp eel meal were placed in zip-lock bags and stored in a cool, dry place until these were used in the experiment.

Nutrient Analysis of the Asian Swamp Eel Meal (ASEM). A 200-gram sample of ASEM was taken to Qualibet Laboratory Services, Quezon City, Philippines for complete proximate analysis, gross energy and calcium and phosphorus determination. Lysine and methionine contents of the test feed material were determined from a 40-g sample at Adamson University Technological Research Laboratory, Adamson University (Result shown in table 2)

\section{Experiment 2 -Digestion Trial}

Preparation of the test feed material. Gelatin capsules with $500 \mathrm{mg}$ capacity were procured and provided for encapsulating ASEM to facilitate deglutition by experimental chickens during the digestion trial.

Experimental birds and cages. Forty finished broilers weighing between $1.5-2.0 \mathrm{~kg}$ were used in the digestion trial. The experimental birds were divided and assigned to two 20-bird lots.

Feeding the experimental birds. Birds in both lots were fasted for a 36-hour period. After this fasting period, birds in Lot 2 were forced-fed with encapsulated finely ground ASEM. Birds in Lot 1 were not fed to provide data for metabolic and endogenous losses (Sibbald, 1986; cited by Lopez, 1993).

Excreta collection. Collections of excreta samples were done in clean plastic trays placed below the caged birds. Collection of excreta in Lot 1 was done 36 hours after fasting. Excreta collection in Lot 2 was done 36 hours after feeding. Collected excreta were cleaned and freed from feathers, scales and other impurities. These were sufficiently aired-dried to allow grinding to meal form. Ground excreta were placed in zip-lock plastic bags, stored in a cool, dry place until the time, when it was taken to a nutrition laboratory for chemical analysis.

Chemical analysis. A 200-gram ground excreta sample of both lots were brought to Qualibet Testing Services Corporation, Quezon City, Philippines for complete proximate analysis, gross energy, calcium and phosphorus determination, while a 40-gram sample was taken to Adamson University Technological Research \& Development Center for lysine and methionine analysis.

Table 1: Chemical analysis of chicken manure from Asian Swamp Eel Meal (ASEM)-fed and fasted broilers

\begin{tabular}{|c|c|c|c|}
\hline Nutrients & Manure from ASEM-Fed Broilers & Manure from Fasted Broilers & Methods \\
\hline Crude protein, $\%$ & 98.95 & 77.86 & Kjeldahl \\
\hline Crude fiber, $\%$ & 1.49 & 3.38 & Fibertech \\
\hline Crude fat, $\%$ & 6.27 & 6.77 & Acid Hydrolysis \\
\hline Moisture, $\%$ & 11.06 & 12.37 & Oven drying \\
\hline Ash, $\%$ & 17.87 & 13.31 & Ignition \\
\hline Gross energy, $\mathrm{kcal} / \mathrm{100 \textrm {g }}$ & 309.67 & 317.61 & Photometric \\
\hline Phosphorous $\%$ & 2.69 & 2.21 & Dry ash Method \\
\hline Calcium $\%$ & 4.40 & 1.54 & GC \\
\hline Lysine, $\mathrm{mg} / \mathrm{kg}$ & 874.70 & 474.27 & GC \\
\hline Methionine, $\mathrm{mg} / \mathrm{kg}$ & 15.32 & 6.10 & \\
\hline
\end{tabular}

Digestibility determination. Apparent digestibility was determined by subtracting the nutrients in the excreta from those in the feed and dividing by nutrient intake. Digestibility of nutrients from the ASEM was determined following the true metabolizable energy (TME) system of Sibbald (1986). This was done to establish the apparent metabolizable energy (AME) and true metabolizable energy (TME), total and available lysine and methionine, and total and available calcium and phosphorus values of ASEM. Apparent metabolizable energy was determined as the difference between the energy in the feed and that in the excreta divided by the energy in the feed.
True metabolizable energy was determined as the difference between AME in birds fed with the test ingredient in Lot 2 and that of energy found in the metabolic and endogenous losses from the fasted birds in Lot 1.

\section{Results and Discussion}

\section{Nutrient composition of Asian Swamp Eel Meal (ASEM)}

Crude protein (CF). Asian swamp eel meal has about 69\% $\mathrm{CP}$ content on dry matter basis (Table 2). On fresh weight basis, Nurhasan et al (2009) reported the CP content of 


\section{International Journal of Science and Research (IJSR) \\ ISSN (Online): 2319-7064}

Index Copernicus Value (2013): 6. 14 | Impact Factor (2015): 6. 391

swamp eel as $19.70 \mathrm{~g}$ per $100 \mathrm{~g}$ sample. The CP content of ASEM as observed in the present study is $6 \%$ higher than that of Peruvian fish meal. This finding suggests that relative to crude protein contents, ASEM can efficiently replace Peruvian fish meal in broiler diets.

Asian swamp eel meal used in the present study also contains high levels of the most limiting essential amino acids (EAA) lysine and methionine (Table 2). This finding conforms to the EAA levels in a 100-g sample of fresh swamp eel which revealed $1557 \mathrm{mg}$ lysine and $461.50 \mathrm{mg}$ methionine (Nurhasan et al., 2009).

These levels are higher than those found in Peruvian fish meal with lysine and methionine contents of $40.80 \mathrm{mg} / \mathrm{kg}$ or 4. $80 \%$ and $17.00 \mathrm{mg} / \mathrm{kg}$ or $1.70 \%$, respectively (Feedstuff Yearbook, 1975). Presence of these nutrients in high levels makes ASEM a good substitute for fish meal in broiler diets.

Crude fiber (CF). Crude fiber content of ASEM is low (Table 2) compared to the more fibrous plant protein sources like soybean meal, but higher than the 1. $0 \% \mathrm{CF}$ found in Peruvian fish meal (Feedstuff Yearbook, 1975). Fiber adversely affect digestibility of feedstuffs, but it was assumed that the $3.95 \%$ CF content of ASEM is not high enough to pose a problem when used to substitute fish meal in broiler diets.

A subsequent digestion trial conducted prior to the feeding experiment showed that fiber in ASEM was highly digestible (Table 3 and 4). It was also noted that CF content of ASEM falls within the $\geq 3$. 00 to 4 . $0 \%$ range of broilers' fiber requirement (Swennen et al., 2010). This finding further supports the assumption that ASEM could replace fish meal in broiler diets.

Table 2: Nutrient composition of Asian Swamp Eel Meal as compared to Peruvian Fish Meal

\begin{tabular}{|c|c|c|}
\hline \multirow{2}{*}{ NUTRIENT } & \multicolumn{2}{|c|}{ ANIMAL PROTEIN SOURCE } \\
\cline { 2 - 3 } & $\begin{array}{c}\text { Asian Swamp } \\
\text { Eel Meal }\end{array}$ & $\begin{array}{c}\text { Peruvian Fish } \\
\text { Meal }\end{array}$ \\
\hline Crude protein, (CP) \% & $68.79^{\mathrm{a}}$ & $65.00^{\mathrm{e}}$ \\
\hline Lysine, $\mathrm{mg} / \mathrm{kg}$ & $612.04^{\mathrm{b}}$ & $40.80^{\mathrm{f}}$ \\
\hline Methionine, $\mathrm{mg} / \mathrm{kg}$ & $24.80^{\mathrm{b}}$ & $17.00^{\mathrm{f}}$ \\
\hline Crude fiber (CF), \% & $3.95^{\mathrm{a}}$ & $1.00^{\mathrm{e}}$ \\
\hline Ether extract (EE), \% & $5.21^{\mathrm{a}}$ & $10.00^{\mathrm{e}}$ \\
\hline Nitrogen-free extract (NFE) & $5.35^{\mathrm{c}}$ & $1.00^{\mathrm{e}}$ \\
\hline Ash, \% & $16.70^{\mathrm{a}}$ & $16.00^{\mathrm{e}}$ \\
\hline Calcium, \% & $5.11^{\mathrm{a}}$ & $4.00^{\mathrm{e}}$ \\
\hline Phosphorus, \% & $3.19^{\mathrm{a}}$ & $2.85^{\mathrm{e}}$ \\
\hline Gross energy (kcal/kg) & $3074.10^{\mathrm{a}}$ & $4481.00^{\mathrm{g}}$ \\
\hline Moisture (MC), \% & $9.01^{\mathrm{a}}$ & $9.00^{\mathrm{e}}$ \\
\hline
\end{tabular}

${ }^{a}$ Qualibet Testing Services Corporation, 121 Dangay St., Project 7, Quezon City.

${ }^{\mathrm{b}}$ Adamson University Technology Research \& Development Center (AUTRDC)

${ }^{\mathrm{c}}$ Calculated as the difference of 100 less the sum of the dry matter components ( $\mathrm{CP}, \mathrm{CF}, \mathrm{EE}$, and Ash)

${ }^{\mathrm{d}}$ Commercial fishmeal

${ }^{\mathrm{e}}$ Feedstuff Yearbook. 1975. Ingredient analysis.

${ }^{\mathrm{f}}$ Converted from percentage to $\mathrm{mg} / \mathrm{kg}$ unit of measurement.

${ }^{\mathrm{g}}$ Calculated value
Crude fat or ether extract (EE). Crude fat or EE content of ASEM is only 5. 21\% (Table 2). Findings of Nurhasan et al (2009) revealed an even lower fat content of $0.80 \mathrm{~g}$ per100g sample of fresh swamp eel. Fat or ether extract content of ASEM in the present study is about $48 \%$ lower than fat found in Peruvian fish meal, which is derived from anchovy(http://www.fao.org/docrep/q3567e/q3567e03.htm), an oily fish (https://en.wikipedia.org/wiki/Anchovy).

The low fat content could be attributed to seasonal variations in areas where Asian swamp eels reproduce. Normally, body lipid content increases before the reproduction period, which takes place in the wet season (Ackman, 1990; Kolakowska et al., 2002). This observation could be true with the Asian swamp eel that were collected and used in the present study. The Asian swamp eel spawns during summer (http://myfwc.com/wildlifehabitats/profiles/freshwater/nonn atives/swamp-eel/), and the possibility of low body lipid contents would be high after spawning. Since collection was done after spawning, ASEM derived from the collected eels tended to have low fat contents. Nurhasan et al (2009) mentioned that fat contents of fish used in their study were low since the samples were collected at the end of the dry season when fat content would have been at the minimum.

Nitrogen-free extract (NFE). Nitrogen-free extract comprise the soluble carbohydrates fraction of most feed materials, which is also true for ASEM. This component is calculated as the difference of 100 less the sum of the dry matter fractions (CP, CF, EE and Ash). Calculated NFE content of ASEM revealed a low level of soluble carbohydrates which is around 5. $35 \%$ (Table 2). This level of NFE however, is $435 \%$ higher compared to the $1.0 \%$ NFE content of Peruvian fish meal. Other reports disclosed that Asian swamp eel meal does not contain carbohydrates (Vishwanath et al. 1998). Low level or even absence of NFE in ASEM and in most feedstuffs of animal origin is attributed to the very little amount (around 1\%) and short duration (12-24 hours) of carbohydrate storage in animal tissues (Maynard et al., 1980).

Ash, calcium (Ca) and Phosphorus (P). Ash content of Asian swamp eel meal is comparable to that of Peruvian fish meal. Asian swamp eel meal and Peruvian fish meal contain approximately $16.70 \%$ and $16.00 \%$ ash, respectively (Table 2 ). Ash reflects the mineral component of all feedstuffs, but does not specify which minerals are found in this fraction. Two of the most abundant minerals in the ash fraction namely $\mathrm{Ca}$ and $\mathrm{P}$, are considered in the present study.

Calcium and phosphorus contents of ASEM are higher than those found in Peruvian fish meal (Table 2). Calcium content of ASEM was about $28 \%$ higher than $\mathrm{Ca}$ in Peruvian fish meal. Phosphorus was approximately $12 \%$ higher in ASEM compared to $\mathrm{P}$ content of fish meal. The higher levels of $\mathrm{Ca}$ and $\mathrm{P}$ in ASEM as compared to Peruvian fish meal could be attributed to the inclusion of more and larger bones of swamp eel during ASEM preparation.

The swamp eel have larger bones due to its bigger size. Body length at maturity is about $1.0 \mathrm{~m}$ (http://fl. biology. usgs.gov/Nonindigenous_Species/Swamp_eel_FAQs/swamp _eel_faqs.html). Bones of anchovy, the main fish species 


\section{International Journal of Science and Research (IJSR) \\ ISSN (Online): 2319-7064 \\ Index Copernicus Value (2013): 6. 14 | Impact Factor (2015): 6. 391}

comprising Peruvian fish meal on the other hand, are less and smaller in size than bones of swamp eel, hence, lower amounts of $\mathrm{Ca}$ and $\mathrm{P}$ are expected. Higher levels of $\mathrm{Ca}$ and $\mathrm{P}$ makes ASEM a good source of these minerals, reducing the inclusion of commercial $\mathrm{Ca}$ and $\mathrm{P}$ sources in broiler diets, hence, cutting costs.

Gross energy (GE). Gross energy content of ASEM is 46\% lower than the GE found in Peruvian fish meal. The low GE level in ASEM could be attributed to its equally low fat and NFE fractions (Table 2). This observation is further warranted since anchovies, from which Peruvian fish meal is derived, are considered oily fish (https://en.wikipedia.org/wiki/Anchovy), which translates to high energy contents of the finished product.

Moisture (MC). Knowing the moisture content of a feed ingredient is important since it affects the weight of the feed, but does not provide nutrient value to the animal. Although animals do have a requirement for water, providing water through an actual water source, instead of through feed ingredients,

is necessary (http://articles.extension.org/pages/11315/dry-matterdetermination\#. Vk4uDb8nYUk).
Water content of ASEM as used in the study is within the level of 9. $0 \%$, which is similar to Peruvian fish meal (Table 2). Based on MC standards for feed ingredients, the $9.0 \%$ level in ASEM is below the $10-14 \%$ range of moisture contents of most dry feedstuffs (PCARRD, 2006).

Lower MC of feeds increases the concentration of DM in feedstuffs, hence facilitating a more uniform feed formulation. Determining the DM content of feed provides a measure of the amount of a particular feed that is required to supply a set amount of nutrients to the animal. Increases or decreases in feed DM content result in over or under feeding of nutrients

(http://articles.extension.org/pages/11315/dry-matterdetermination\#.Vk4uDb8nYUk).

\section{Digestibility of Asian Swamp Eel Meal (ASEM)}

Proximate analysis indicates the concentration of nutrients present in feedstuffs but does not indicate its feeding value since it does not consider the availability of nutrients to the animal. A digestion trial should be conducted to better assess the nutritive value of feedstuffs. A digestion trial therefore was conducted to evaluate the digestibility of ASEM in general, and its proximate components in particular.

Table 3: Digestibility of Asian swamp eel meal by broilers

\begin{tabular}{|c|c|c|c|c|c|c|c|}
\hline & \multirow{2}{*}{ Crude Protein } & \multirow{2}{*}{ Lysine } & \multirow{2}{*}{ Met } & \multicolumn{3}{|c|}{ Carbohydrates } & Ether \\
\cline { 5 - 6 } & & & & Crude Fiber & Nitrogen- Free Extract & Extract \\
\hline Intakeof1470g dry matter containing, g & 1011.21 & 0.90 & 0.04 & 58.07 & 78.64 & 76.59 \\
\hline Output of 525g dry matter, containing, g & 110.72 & 0.21 & 0.01 & 7.82 & 0.00 & 32.92 \\
\hline Digested feed/nutrients, g & 900.49 & 0.69 & 0.03 & 50.25 & 78.64 & 43.67 \\
\hline Digested feed/nutrients, \% & 89.05 & 76.63 & 86.72 & 86.53 & 100.00 & 57.02 \\
\hline
\end{tabular}

Nitrogen-free extract. The digestion trial revealed that out of the intake of $1470 \mathrm{~g}$ ASEM containing 78. $64 \mathrm{~g}$ of nitrogen-free extract (NFE), no traces of this nutrient were found in the excreta indicating that these nutrients were totally digested and absorbed by the experimental birds (Table 3). This observation suggests a high digestibility of NFE fraction in ASEM as the $100 \%$ digestion coefficient show (Table 11). This is probable since NFE is composed primarily of soluble and readily available carbohydrates such as sugars and starches (CTAHR, n. d. ), which are easily digested, dissolved and absorbed in the gut.

Table 4: Digestion coefficients of the different proximate components of Asian swamp eel meal

\begin{tabular}{|c|c|c|c|}
\hline Nutrient & $\begin{array}{c}\text { Total nutrient } \\
\text { per } 100 \mathrm{~g} \text { of } \\
\text { feed, } \mathrm{g}\end{array}$ & $\begin{array}{c}\text { Digestion } \\
\text { coefficients, } \\
\%\end{array}$ & $\begin{array}{c}\text { Digestible } \\
\text { nutrients, } \\
\mathrm{g}\end{array}$ \\
\hline Crude protein & 68.79 & 89.05 & 61.26 \\
\hline Lysine & $(0.061)$ & $(76.63)$ & $(0.047)$ \\
\hline Methionine & $(0.002)$ & $(86.72)$ & $(0.002)$ \\
\hline Crude fiber & 3.95 & 86.53 & 3.42 \\
\hline Nitrogen-free extract & 5.35 & 100.00 & 5.35 \\
\hline Ether extract & 5.21 & $\begin{array}{c}57.02(\mathrm{x} 2 . \\
25)\end{array}$ & 6.68 \\
\hline $\begin{array}{c}\text { Total Digestible } \\
\text { Nutrients }\end{array}$ & & & 76.710 \\
\hline
\end{tabular}

Crude protein. Protein digestibility ranked next to NFE with a digestion coefficient of approximately $89 \%$ (Table 4 ). This coefficient value indicates that around 900. $49 \mathrm{~g}$ of protein was digested from the 1011. $21 \mathrm{~g}$ of protein found in ASEM when experimental broilers were fed with $1470.0 \mathrm{~g}$ of this feedstuff (Table 3). The high protein digestibility in ASEM reflects an equally high biological value, which translates to more efficient protein utilization and feed conversion, higher weight gains and faster growth rates of broilers that were used in the feeding trial. . .

Observed digestion coefficient of ASEM protein conforms to apparent digestibility coefficient (ADC) values of various feed ingredients which were generally high, especially for animal proteins(Gomes et al. 1995). The 89. 05\% apparent digestibility coefficient (ADC) of ASEM protein however, is higher than the $79 \%$ ADC for fish meal protein (Ravindran et al., 2005).

Lysine and methionine. Digestibility of the two of the most limiting amino acids in ASEM, i. e., lysine and methionine varied. Lysine, with a digestion coefficient of $76.63 \%$, was less efficiently digested than methionine with $86.72 \%$ ADC (Table 4). Apparent digestibility coefficient for lysine in ASEM is lower compared to the digestion coefficient (86\%) of same amino acid in fish meal. On the other hand, ADC for methionine in ASEM was slightly higher than that of fish meal with $86 \%$ ADC (Lemme et al., 2004). Apparent digestibility coefficient of lysine in ASEM is likewise lower compared to digestibility coefficients of lysine in commonly used feed ingredients of animal origin like blood meal, 0.87; fish meal, 0.84; meat meal, 0.69; meat and bone meal, 


\section{International Journal of Science and Research (IJSR) \\ ISSN (Online): 2319-7064 \\ Index Copernicus Value (2013): 6. 14 | Impact Factor (2015): 6. 391}

0.64; and feather meal, 0.56. Apparent digestibility coefficient of methionine in ASEM however, nearly approached that of blood meal, and higher than that of fish meal, meat meal, meat and bone meal, and feather meal (Ravindran et al., 2005). Apparently, Ravindran et al. (2005) rated the ADC of amino acids in the foregoing animal protein sources as: high for blood meal, intermediate for fish meal, and low for meat meal, meat and bone meal, and feather meal.

Based from qualitative ratings for ADC for different amino acids in the foregoing animal protein sources, ADC for lysine in ASEM could be rated as intermediate, and that of methionine, high. Nevertheless, the apparent digestibility coefficient values for lysine and methionine contents of ASEM conformed to the standardized ileal digestibility coefficients of most feedstuffs of animal origin for broilers which ranged from 46-86\% (Lemme et al., 1004).

Such conformity of ASEM lysine and methionine ADC with standardized ileal ADC values were obtained although the former values were derived from a digestibility trial with precision-fed intact broilers.

Crude fiber (CF). Fiber content of ASEM is highly digestible with ADC of $86.53 \%$ (Table 4) indicating that out of $58.07 \mathrm{~g}$ of CF in the test material, $50.23 \mathrm{~g}$ were digested. This finding is contrary to the premise that fiber is not efficiently digested by poultry and that; dietary fiber is considered diluents of the diet and, often, an anti-nutritional factor (Mateos et al., 2011). Findings of the present study however, suggest that ASEM contains soluble fiber, which broilers could easily and efficiently digest.

Ether extract (EE) or crude fat. When fed to broilers, ether extract (EE) or crude fat in ASEM has a digestibility coefficient of $57.02 \%$, which is lower compared to the ADC of other proximate components like CP, CF and NFE (Table 4). This finding conformed to a report that fat digestibility is species dependent, where it is lower in poultry than in pigs.

Age of the animal also influence fat digestibility, where it is lower in young animals than in mature ones (Schothorst Feed Research, 2015). The digestion of regular fats and oils, which are usually long-chain triglycerides, requires bile acids as well as lipases (Enig, 2004). Young birds have a low level of natural lipase production and a low rate of bile salt production and therefore have a limited fat digestion (Rovers, 2013). These findings of previous studies justify the low fat digestibility noted in the present study where immature broilers were used in the digestibility trial.

Fat is digested more slowly than either protein or carbohydrate, and is generally thought that there is a problem with digestion of fat; however, the slow digestion is really only nature's way of maintaining an even amount of energy distribution within the animal (Enig, 2014).

Total digestible nutrients (TDN). Total digestible nutrients in ASEM are comparable or even higher than the TDN levels in most protein concentrates used in animal feed formulations. On as fed basis, TDN of ASEM is comparable to that of soybean meal but higher than that of fish meal (PCARRD, 2006). This level is attributed to the high dry matter digestibility in ASEM particularly protein, fiber, and nitrogen-free extract (Table 4). Although TDN level serve as dietary energy measure in ruminant nutrition, its use as a criterion in evaluating energy value of feedstuffs has significance even for non-ruminants like poultry. The high TDN contents of ASEM therefore could justify its use as an alternative protein source to substitute fish meal in broiler diets.

Apparent digestible energy (ADE). Apparent digestible energy reflects the difference between the gross energy of ASEM and that of the broiler fecal material. It represents the amount of energy that was supposed to be digested and absorbed by the experimental birds. Apparent digestible energy is not an appropriate energy measure in poultry nutrition but its importance lies on the fact that it served as the basis in estimating metabolizable energy.

Table 5: Apparent digestible energy, apparent metabolizable energy and zero Nitrogen balance-corrected AME Contents of Asian swamp eel meal on as-fed basis.

\begin{tabular}{|l|l|}
\hline Particulars & Energy \\
\hline Dry matter intake of $1470 \mathrm{~g}$, containing, $\mathrm{kcal} / \mathrm{kg}$ & 4518.93 \\
\hline Dry matter output of $525 \mathrm{~g}$, containing, $\mathrm{kcal} / \mathrm{kg}$ & 442.89 \\
\hline Apparent digestible energy, $\mathrm{kcal} / \mathrm{kg}$ & 4076.04 \\
\hline Apparent metabolizable energy, $\mathrm{kcal} / \mathrm{kg}$ & 3260.83 \\
\hline Zero N-corrected AME, $\mathrm{kcal} / \mathrm{kg}$ & 3238.00 \\
\hline Apparent digestibility coefficient, \% & 90.20 \\
\hline
\end{tabular}

Digestible energy in ASEM is high approaching a level of 4076. $04 \mathrm{kcal} / \mathrm{kg}$. This level could be ascribed to the high digestibility coefficients of NFE and protein, and intermediate digestibility of fat in ASEM, these nutrients being the energy sources in the test feedstuff.

Metabolizable energy (ME). An appropriate measure of energy in poultry nutrition in this study, metabolizable energy is categorized as apparent metabolizable energy (AME) and zero nitrogen balance-corrected AME. Similar to digestible energy, AME value is high at $3260.83 \mathrm{kcal} / \mathrm{kg}$ of ASEM (Table 5). This level meets the ME requirement of broilers which ranged from $2700-3000 \mathrm{kcal} / \mathrm{kg}$ for the different types of feeds for meat type chickens (Mateo et al.,, 1996). This holds true of zero N-balance AME with a value of $3238 \mathrm{kcal} / \mathrm{kg}$. Based from these AME values, it can be inferred that in terms of the broiler's energy needs, ASEM could safely and efficiently substitute fish meal in the bird's diet.

Apparent energy digestibility coefficient (AEDC). Dietary energy from ASEM is efficiently digested as the high AEDC value of 90. 20\% show (Table 5). Presence of highly digestible proteins, carbohydrates and fats which are the primary dietary energy sources in ASEM, contributed to the generation of high levels of DE and ME. This translated to an equally high digestibility coefficient.

Digestible calcium (Ca). Calcium digestibility coefficient is high at around $80.01 \%$ (Table 6). This indicates that out of $1470 \mathrm{~g}$ ASEM dry matter intake containing $75.12 \mathrm{~g} \mathrm{Ca}$, 


\section{International Journal of Science and Research (IJSR) \\ ISSN (Online): 2319-7064}

Index Copernicus Value (2013): 6. 14 | Impact Factor (2015): 6. 391

approximately $60.10 \mathrm{~g}$ were found available in the experimental birds after analysis of the dry matter output of $525 \mathrm{~g}$ revealed a Ca content of $15.02 \mathrm{~g}$. While digestibility of the inorganic (Ash) fraction of feedstuffs like Cais not typically considered in digestion trials, information on availability of these minerals in the feed is important in broiler nutrition, especially in formulating rations for normal bone formation and development.

Digestible phosphorus (P). Phosphorus in ASEM is more digestible and hence, more available than $\mathrm{Ca}$ as the high coefficient of digestibility of $94.63 \%$ show (Table 6). This observation indicates that out of the $49.89 \mathrm{~g}$ total $\mathrm{P}$ in $1470 \mathrm{~g}$ of ASEM dry matter, approximately $44.37 \mathrm{~g}$ was digested and considered available to the experimental birds. This coefficient of digestibility nearly approached the $100 \%$ level of available $\mathrm{P}$ in fish meal (Buyoc et al., 1996).

Table 6: Available calcium and phosphorus contents of Asian swamp eel meal on as-fed basis

\begin{tabular}{|c|c|c|}
\hline Particulars & Calcium & Phosphorus \\
\hline Dry matter intake of $1470 \mathrm{~g}$, containing, g & 75.12 & 46.89 \\
\hline Dry matter output of 525 g, containing, g & 15.02 & 2.52 \\
\hline Digested calcium, g & 60.10 & \\
\hline Coefficient of calcium digestibility, \% & 80.01 & \\
\hline Digested phosphorus, g & & 44.37 \\
\hline Coefficient of phosphorus digestibility, \% & & 94.63 \\
\hline
\end{tabular}

\section{Summary, Conclusion and Recommendations}

\subsection{Summary}

This study was conducted to determine the nutrient composition of Asian swamp eel meal; evaluate the digestibility of Asian swamp eel meal in broilers nutrition.

Specifically, this study was carried out to a)determine the nutrient composition of Asian swamp eel meal as compared to Peruvian fish meal b) determine and evaluate the digestion coefficients and the total digestible nutrient of the different proximate components, c) determine and evaluate the digestibility of the apparent digestible energy, apparent metabolizable energy and zero Nitrogen balance-corrected AME Contents of Asian swamp eel meal on as-fed basis and, d) determine and evaluate the digestibility of calcium and phosphorus contents of Asian swamp eel meal on as-fed basis. ;

The study was divided into two experiments namely; nutrient composition determination, and digestion trial. The digestion trial was conducted for five days. Forty heads of finished broilers were used in the experiment. The experimental broilers were divided and assigned to two 20bird lots. Birds in both lots were fasted for 36 hours period. Birds in Lot 2 were forced -fed with encapsulated finely ground ASEM. Collections of excreta in both lots were done 36 hours after fasting and after feeding. Collected excreta from both lots were separately air-dried, placed in ziplocked plastic bags, and chemically analyzed. Results are summarized below:

\section{Nutritive Value and Digestibility of ASEM}

1) Asian swamp eel meal contained high levels of crude protein, calcium and phosphorous, and the limiting essential amino acids lysine and methionine;

2) Most nutrients in ASEM have high digestion coefficients

\subsection{Conclusion}

Based from the results of the study, Asian swamp eel meal contains high levels of crude protein, calcium, phosphorous and limiting amino acids lysine and methionine. The digestibility study revealed that most of the nutrients in ASEM have high digestion coefficients.

\section{3 Recommendations}

Based from the findings of the study, further studies considering the total amino acid profile and digestibility of these amino acids is also suggested

\section{References}

[1] ACKMAN, R. G. 1990. Seafood lipids and fatty acids. Food Rev. Int. 6, 617-646.

[2] BUYOC, M. C., F. SD. PASCUAL, L. J. QUERUBIN, S. P. ACDA, P. F. ALCANTARA, E. D. CORDOVA, A. L. BATILANDO, B. A. OLIVEROS and A. N. DEL BARRIO. 1996. Nutrient Composition of Common Feed Ingredients. In: PHILSAN Feed Reference Standards. Second Edition: Philippine Society of Animal Nutritionists.

[3] ENCYCLOPAEDIA BRITANNICA. 2000. Deluxe Compact Disc. Britannica.com.

[4] ENIG, M. G. 2004. Digestion and Absorption of Food Fats. The Weston A. Price Foundation: For Wise Traditions in Food, Farming and the Healing Arts. Available: Internet:http://www.westonaprice. org/health-topics/digestion-and-absorption-of-foodfats/. Accessed: 27 November 2015.

[5] . 2004. Know Your Fats: The Complete Primer for Understanding the Nutrition of Fats, Oils, and Cholesterol. Bethesda Press, Silver Spring, Maryland, 2000.

[6] EN-WIKIPEDIA. ORG/WIKI/MONOPTERUS ALBUS 2013.

[7] FEEDSTUFF YEARBOOK. 1975. Ingredient analysis. In: Supnet, M. G. (ed. ). 1980. Pork Production Manual. Second Edition. University of the Philippines at Los Baños, College, Laguna, Philippines. 381 pp.

[8] FLORIDA FISH AND WILDLIFE CONSERVATION COMMISSION, IMAGE CREDIT: DIANE PEEBLES (2013). Swamp Eel: Monoptrusalbus. http://myfwc.com/wildlifehabitats/profiles/fish/fresh water/nonnatives/swamp-eel/5Accessed: 11 June 2014.

[9] FOOD AND AGRICULTURE ORGANIZATION. 1995. Poultry feed availability and nutrition in developing countries: Poultry Development Review. . n. d. FAO Corporate Document Repository. Fish Feeds and Feeding in Developing Countries. Available: Internet: http://www.fao. org/docrep/q3567e/q3567e03.htm Accessed: 21 November 2015. Accessed: 31 October 2015. 


\section{International Journal of Science and Research (IJSR) \\ ISSN (Online): 2319-7064}

Index Copernicus Value (2013): 6. 14 | Impact Factor (2015): 6. 391

[11] FULLER, P. L., L. G. NICO, M. CANNISTER, and M. NEILSON (2013). Monoptrusalbus(Zuiew, 1793) article. Available: Internet: http://nas. er. usgs. gov/queries/FactSheet. aspx?SpeciesID=974. Accessed: 11 June 2014.

[12] GILLESPIE, J. R. 1992. Modern Livestock and Poultry Production. $4^{\text {th }}$ Edition. Canada: Delmar

[13] GOMES, E. F., P. REMA, and S. J. KAUSHIK. 1995. Replacement of fish meal by plant proteins in the diet of rainbow trout (Oncorhynchusmykiss): digestibility and growth performance. Aquaculture, 130: 2-3, 177-186 pp. Available:

Internet. http://www.sciencedirect.com/science/article/pii/004484 8694002116. Accessed: 24 November 2015.

[14]HAMILTON H. 2006. Frequently Asked Questions about the Asian Swamp Eel. Florida Integrated Science Center: USGS. 17 March 2006. http://cars. er. usgs. gov/Nonindifenous_Species/Swamp_eel_FAQs/swamp eel_faqs.html. Accessed: 16 April 2015.

[15] http://articles. extension. org/pages/11315/dry-matterdetermination\#. Vk4uDb8nYUk.

[16] http://dx. doi. org/10. 1016/S0308-8146(97)00108-8.

[17] https://en. wikipedia. org/wiki/Anchovy

[18] http://fl. biology. usgs. gov/Nonindigenous_Species/Swamp_eel_FAQs/swamp eel_faqs.html

[19] http://myfwc.com/wildlifehabitats/profiles/fresh water/nonnatives/swamp-eel

[20] http://www.fao. org/docrep/q3567e/q3567e03.htm)

[21] https://www-google.com-ph/search=journals on asian swamp eel.

[22] KOLAKOWSKA, A., J. N. OLLEY, and G. A. DUNSTAN. 2002. Fish lipids. In: Zdzisław, E., Sikorski, Anna Kołakowska, (Eds. ), Chemical and Functional Properties of FoodLipids. CRC Press, p. 388.

[23] LEMME, A., V. RAVINDRAN and W. L. BRYDEN. 2004. Ileal digestibility of amino acids in feed ingredients for broilers. World's Poultry Science Journal, 60:423-438 pp. Available: Internet. http://journals. cambridge. org/action/displayAbstract?fromPage $=$ online\&aid $=6237$ 52. Accessed: 25 November 2016.

[24] MANILA BULLETIN. 2011. Gods and the Rice Terraces. News paper article. December 12, 2011. Available: Internet: https://ph. news. yahoo.com/godsrice-terraces-022115240.html. Accessed: 15 June 2015.

[25]MATEO, J. P., C. C. LAZARO, P. F. ALCANTARA, E. S. LUIS, J. O. CONCEPCION, C. A. VALDEZ, A. P. JAUHARI, M. C. BUYOC, M. P. LAGMAY, G. D. LUGOD, J. B. CRUZ, F. SD. PASCUAL, S. P. ACDA, and M. P. MERCADO. 1996. Nutrient Recommendations for Poultry. In: PHILSAN Feed Reference Standards. Second Edition. Philippine Society of Animal Nutritionists.

[26]MATEOS, G. G., E. JIMÉNEZ-MORENO, M. P. SERRANO, and R. P. LÁZARO. 2011. Poultry response to high levels of dietary fiber sources varying in physical and chemical characteristics. The Journal of Applied Poultry Research, 21(1):156-174 pp. Available: Internet. http://japr.oxfordjournals. org/content/21/1/156.full. Accessed: 25 November 2015.

[27] MAYNARD, L. A., J. K. LOOSLI, H. F. HINTZ and R. G WARNER. 1980. Animal Nutrition. Seventh Edition. McGraw-Hill Book Company, 1221 Avenue of the Americas. New York, New York 10020. 601 pp.

[28] NURHASAN, M. 2008. Nutritional Composition of Aquatic Species in Laotian Rice Field Ecosystems; Possible Impact of Reduced Biodiversity. Master's Thesis in International Fisheries Management. Department of Marine Biotechnology, Norwegian College of Fishery Science, University of Tromsø. PDF Document. Available, Internet: https://www.ub. uit. no/munin/bitstream/handle/10037/1434/thesis. pdf? Accessed: July 15, 2014.

[29] PCARRD. 2006. The Philippines Recommends for Livestock Feed Formulation. Philippines Recommend Series no. 64-D, 122-127 pp. Department of Science and Technology, Los Baños, Laguna.

[30] PEEBLES, D. 2013. Swamp Eel: Monoptrusalbus. FloridaFish and wildlife Conservation Commission, image credit: en-wikipedia. org/wiki/momopterusalbus. http://myfwc.com/wildlifehabitats/profiles/fish/fresh water/nonnatives/swamp-eel/5. Publisher, Inc.

[31] RAVINDRAN, V., L. I. HEW, G. RAVINDRAN and W. L. BRYDEN. 2005. Apparent ileal digestibility of amino acids in dietary ingredients for broiler chickens. Animal Science, 81:85-97 pp. Available: Internethttp:/www.researchgate. net/publication/ $231915547 \quad$ Apparent_ ileal_ digestibility of_amino_acids_in_feed_ingredient for broiler chickens. Accessed: 30 November 2015.

[32] SCHOTHORST FEED RESEARCH. 2015. Animal fat: Nutritious ingredient for animal diets. ALL ABOUTFEED. Volume 23, No. 5, 2015. Available: Internet: https://schoth orst. $\mathrm{nl} /$. /Animal_fat_Nutritious_ingredient_for_animal_die. Accessed: $2 \overline{7}$ November 2015.

[33] SMITH, C. 2009. Invasive ALERT: Asian Swamp Eel. Retrieved June 11, 2014 at http://www.nj. gov/dep/fgw/pdf/fwfishesies/invasive_swampeel09. pdf.

[34] SWENNEN, Q., N. EVERAERT, M. DEBONNE, I. VERBAEYS, C. CAREGHI, K. TONA, G. P. J. JANSSENS, E. DECUYPERE, V. BRUGGEMAN, and J. BUYSE. 2010. Effect of macronutrient ratio of the pre-starter diet on broiler performance and intermediary metabolism. J. Anim. Physiol. Anim. Nutria. 94:375-384.

[35] VISHWANATH, W., H. LIBATI and M. BIJEN. 1998. Biochemical, Nutritional and Microbiological Quality of Fresh and Smoked Mud Eel Fish (Monoptrusalbus): A Comparative Study of Food Chemistry. 61:1-2, 153$156 \mathrm{pp}$.

[36] www.columbia.edu/itc/cerc/danoff-burg/. /Monopterus_albus.html 